\title{
Voltage sensitivity of NMDA-receptor mediated postsynaptic currents
}

\author{
A. Konnerth ${ }^{1}$, B.U. Keller ${ }^{1}$, K. Ballanyi ${ }^{1 *}$, and Y. Yaari ${ }^{2}$ \\ 1 Zelluläre Neurophysiologie, Max-Planck-Institut für biophysikalische Chemie, Postfach 2841, \\ D-3400 Göttingen, Federal Republic of Germany \\ ${ }^{2}$ Department of Physiology, Hebrew University-Hadassah Medical School, Jerusalem 91010, Israel
}

Received January 18, 1990 / Accepted February 22, 1990

Summary. Patch-clamp techniques were used to record pharmacologically-isolated N-methyl-D-aspartate-mediated excitatory postsynaptic currents (NMDA-EPSCs) from dentate granule cells in thin rat hippocampal slices. Membrane voltage modulated these EPSCs in two ways. Firstly, depolarization from resting potential enhanced EPSC amplitudes, as expected for a voltage-dependent block by $\mathrm{Mg}^{2+}$ of synaptically activated NMDA receptor channels. Secondly, depolarization markedly prolonged the time course of decay of NMDA-EPSCs in normal and low extracellular $\mathrm{Mg}^{2+}$. Both mechanisms were complementary in establishing a strong dependence between membrane potential and the amount of charge, namely $\mathrm{Ca}^{2+}$, transferred through synaptically activated NMDA receptor channels, that presumably underlies induction of long-term potentiation in the hippocampus.

Key words: NMDA - Excitatory postsynaptic current Voltage sensitivity - Patch clamp - Thin hippocampal slice - Rat

\section{Introduction}

Activation of postsynaptic N-methyl-D-aspartate (NMDA) receptors by excitatory amino acid neurotransmitters plays a crucial role in long-term potentiation and other forms of neuronal plasticity in the mammalian brain (Collingridge and Bliss 1987). However, technical difficulties have so far precluded high resolution analysis of NMDA-receptor mediated excitatory postsynaptic currents (NMDA-EPSCs) at specific central synapses. Applying patch-clamp techniques to thin rat hippocampal slices (Edwards et al. 1989) allowed us to record pharmacologically isolated NMDA-EPSCs from visually identified central neurones in situ. We report here

* Present address: Physiologisches Institut der Universität Göttingen, D-3400 Göttingen, FRG

Offprint requests to: A. Konnerth (address see above) that the time course of decay of these EPSCs is strongly dependent on membrane voltage, being prolonged by depolarization in an exponential manner. The data indicate, that even moderate depolarizations prolong the duration of NMDA-EPSCs, which is a critical determinant of NMDA-receptor-mediated modifications of neuronal function (Gustafsson et al. 1987; Larson and Lynch 1989).

\section{Methods}

The techniques of patch-clamping visually identified neurones in thin slices of mammalian CNS tissue have been described recently (Edwards et al. 1989). We used standard procedures to cut with a vibrating slicer $120-150 \mu \mathrm{m}$ thick transverse hippocampal slices from 18-21 day old rats. After sectioning, the slices were stored at $37^{\circ} \mathrm{C}$ in oxygenated $\left(95 \% \mathrm{O}_{2}, 5 \% \mathrm{CO}_{2}\right)$ saline composed normally of (in mM) NaCl 125, $\mathrm{KCl} 2.5, \mathrm{CaCl}_{2} 2, \mathrm{MgCl}_{2} 1, \mathrm{NaH}_{2} \mathrm{PO}_{4} 1.25$, $\mathrm{NaHCO}_{3} 26$, glucose 25 (pH 7.4). In " $\mathrm{Mg}^{2+}$-free" saline, due to contamination, the $\mathrm{Mg}^{2+}$ concentration measured fluormetrically was $\sim 3 \mu \mathrm{M}$. Slices were transferred to the recording chamber (volume $2 \mathrm{ml}$ ) placed on the stage of an upright microscope, and continously perfused at room temperature $\left(21-24^{\circ} \mathrm{C}\right)$ with either normal or $\mathrm{Mg}^{2+}$-free oxygenated saline, containing $10 \mu \mathrm{M}$ bicuculline methiodide to block GABA-mediated inhibitory postsynaptic currents. When viewed with Nomarski optics at $400 \mathrm{X}$ magnification (using a long working distance water immersion objective), individual granule cells of the dentate were clearly discerned. The cells chosen for recording were "cleaned" by a double step procedure consisting, first, of loosening the surrounding tissue with a stream of saline released from a near by broken patch pipette (tip diameter $5-10 \mu \mathrm{m}$ ), followed by sucking the resulting debris into the pipette (Edwards et al. 1989).

Tight-seal whole-cell (>10 G $\Omega$ ) recordings (Hamill et al. 1981) were made with pipettes having resistances of $4-5 \mathrm{M} \Omega$. The standard pipette (intracellular) solution contained (in $\mathrm{mM}$ ) $\mathrm{CsCl} 120$, tetraethylammonium (TEA) 20, $\mathrm{CaCl}_{2} 1, \mathrm{MgCl}_{2} 2$, Na-ATP 4, EGTA 10, HEPES 10 (pH 7.3). Since ATP is a potent chelator of $\mathrm{Mg}^{2+}\left(K_{\mathrm{d}}=10^{4}\right.$ at $\left.\mathrm{pH} 7.2\right)$ (Martell and Smith 1974), the free intracellular $\mathrm{Mg}^{2+}$ concentration was estimated to be less than $1 \mu \mathrm{M}$. This is far below the intracellular $\mathrm{Mg}^{2+}$ concentrations which block outward currents through other types of neuronal channels (Pusch et al. 1989). 
Synaptic responses were evoked by stimulating focally the afferent fibers near the apical outer border of the granule cell layer (at about $50-200 \mu \mathrm{m}$ from the examined neurone). This region of the dentate gyrus contains fibers of the perforant path, which form excitatory synapses with granule cells (Hjorth-Simonson and Jeune 1972). L-glutamate is assumed to be the transmitter in these synapses (White et al. 1977).

Although space clamp problems are unavoidable in voltage clamp recordings from cells with extended processes, these did not seem to interfere significantly with recordings of the slow NMDA-EPSCs. Thus these currents reversed completely (i.e. without displaying a biphasic reversal) at $-0.3 \pm 2.9 \mathrm{mV}(n=9)$, as expected for NMDA-mediated currents (Engberg et al. 1979; Mayer and Westbrook 1987).

\section{Results and discussion}

EPSCs were recorded from visually identified dentate granule cells in thin hippocampal slices treated with $5 \mu \mathrm{M}$ cyanonitroquinoxaline-dione (CNQX), a specific blocker of non-NMDA (i.e. kainate and quisqualate) receptors (Honoré et al. 1988; Blake et al. 1988). As exemplified in Fig. 1A, small (20-50 pA) EPSCs were consistently seen at resting membrane potentials (ca. $-70 \mathrm{mV}$ ). Their suppression by the specific NMDA-receptor antagonists DL-2-aminophosphonovalerate $( \pm$ APV $; 50 \mu \mathrm{M})$ and 3-(2-carboxypiperazinyl)propyl-phosphonate (CPP; $10 \mu \mathrm{M}$ ) identified them as NMDA-EPSCs (Lambert and Jones 1989; Andreasen et al. 1989).

In several respects the NMDA-EPSCs resembled NMDA-induced currents in cultured central neurones (Nowak et al. 1984; Mayer et al. 1984). Peak EPSC amplitudes increased with depolarization from resting potential, displaying a negative slope conductance at membrane potentials between -70 and $-25 \mathrm{mV}$ (Fig. 1A, C). Perfusing the preparation with nominally $\mathrm{Mg}^{2+}$-free saline markedly enhanced the EPSCs and eliminated the region of negative slope conductance (between -70 and $-25 \mathrm{mV}$ ) observed in $1 \mathrm{mM} \mathrm{Mg}^{2+}$ saline (Fig. 1A, C). However, a region of negative slope conductance was still seen at membrane potentials between -70 and $-90 \mathrm{mV}$, presumably due to NMDA-receptor channel block by residual extracellular $\mathrm{Mg}^{2+}\left(\mathrm{Mg}_{0}^{2+}\right)$. The slight (5-10\%) augmentation of EPSC amplitudes at positive membrane potentials produced by washing out $\mathrm{Mg}_{0}^{2+}$ (Fig. 1A) most probably reflects enhanced release of neurotransmitter from presynaptic terminals (del Castillo and Katz 1954).

The use of the patch-clamp technique allowed a detailed investigation of the time course of NMDA-EPSCs over a wide range of membrane potentials. Whereas the rise times to half amplitude of the EPSCs $(7.4 \pm 2.7 \mathrm{~ms}$; $n=4$ ) were not affected by voltage, their decay phase was strongly voltage-dependent. In all cells tested $(n=21)$, depolarization markedly prolonged the decay time course of NMDA-EPSCs (Fig. 1A). In the range of membrane potentials examined $(-80$ to $+50 \mathrm{mV})$, the decay time course of NMDA-EPSCs could be well fitted by the sum of two exponentials (Fig. 1B). At voltages close to resting potential $(-70 \mathrm{mV})$, in solutions containing $1 \mathrm{mM} \mathrm{Mg}_{0}^{2+}$ the mean time constants of the faster $\left(\tau_{\text {fast }}\right)$ and the slower $\left(\tau_{\text {slow }}\right)$ exponentials were $46 \pm 13 \mathrm{~ms}$
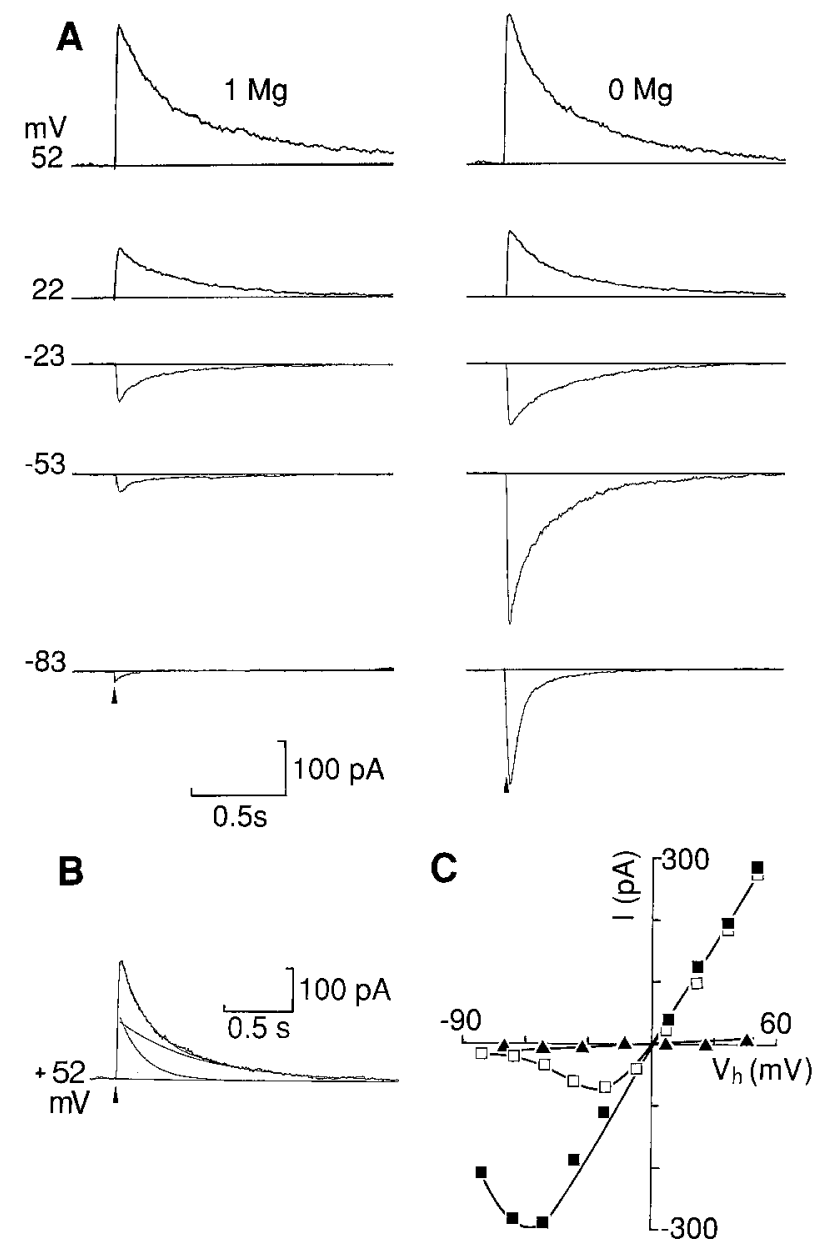

Fig. 1A-C. Pharmacologically-isolated NMDA-EPSCs in rat dentate granule cells. A Effect of washing out of $\mathrm{Mg}_{0}^{2+}$. The EPSCs shown were evoked at different holding membrane potentials in normal saline $(1 \mathrm{Mg})$ and in nominally $\mathrm{Mg}^{2+}$-free saline $(0 \mathrm{Mg})$. B An exemplary NMDA-EPSC (average of 6 consecutive traces) evoked at $+52 \mathrm{mV}$ is fitted by eye with the biexponential function: $f(t)=A_{\text {fast }} \exp \left(-t / \tau_{\text {fast }}\right)+A_{\text {slow }} \exp \left(-t / \tau_{\text {slow }}\right)$. The two separate components of this function are plotted together with the displayed EPSC traces. Time of stimulation is indicated by the arrowheads on the lower traces. C I-V relationship of NMDA-EPSCs in normal saline (open squares) and in nominally $\mathrm{Mg}^{2}$-free saline before (closed squares) and after (triangles ) \pm APV application. Each displayed EPSC represents an average of six consecutive responses

and $235 \pm 38 \mathrm{~ms}(n=4)$, respectively. Both $\tau_{\text {fast }}$ and $\tau_{\text {slow }}$ increased exponentially upon depolarization, changing e-fold for a $83 \pm 16 \mathrm{mV}$ and a $121 \pm 13 \mathrm{mV}(n=4)$ depolarization, respectively (Fig. 2A, B).

Our data agree with previous findings (Dale and Roberts 1985; Forsythe and Westbrook 1988) that both the rise and decay times of NMDA-EPSCs are much slower than those of EPSCs mediated by non-NMDA receptors. It is not yet known whether presynaptic (e.g., slow diffusion of neurotransmitter to extrasynaptic NMDA-receptors) or postsynaptic (e.g., prolonged bursts of NMDA-receptor channel openings (Jahr and Stevens 1987) or NMDA-receptor activation of a second messenger cascade) processes are responsible for this slow time course. We show here that in either case, the final time course of these EPSCs is determined by the 

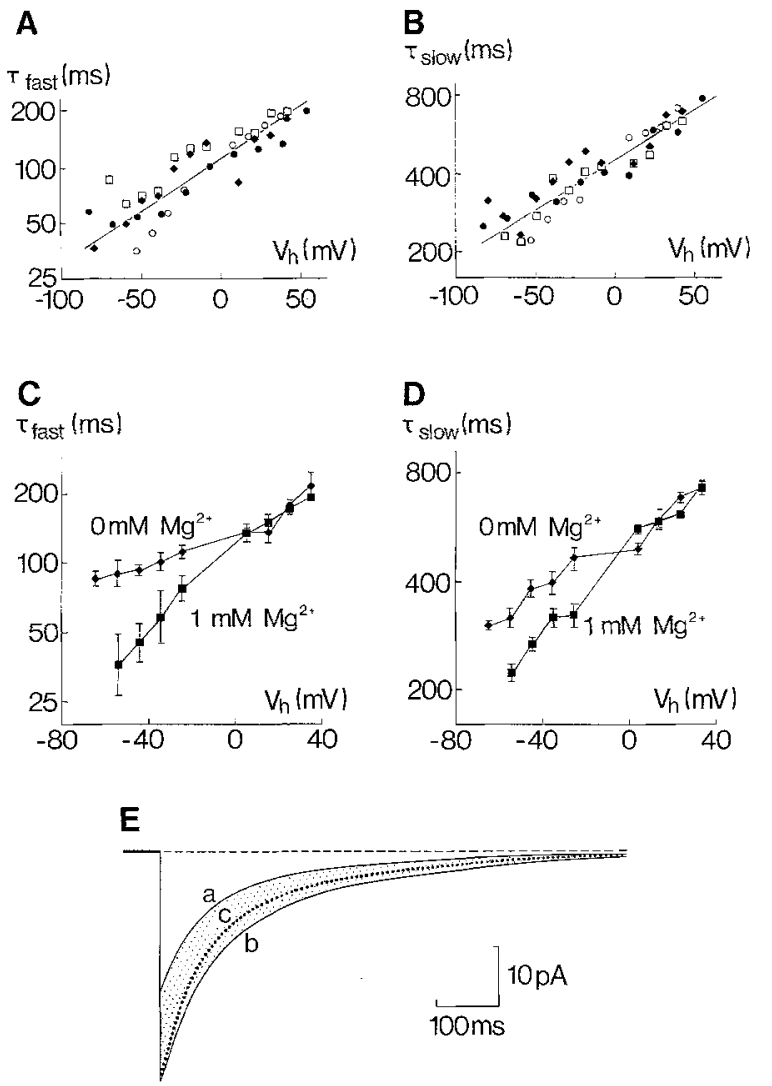

Fig. 2A-B. Voltage sensitivity of decay time course of NMDA-EPSCs in rat dentate granule cells in solutions containing $1 \mathrm{mM} \mathrm{Mg}$. Dependence of $\tau_{\text {fast }}$ on membrane potential (A). Dependence of $\tau_{\text {slow }}$ on membrane potential (B). In both (A) and (B), data pooled from four cells (represented by different symbols) is plotted semilogarithmically. The lines were interpolated by linear regression. The ratios of the amplitudes $A_{\text {fast }} / \mathrm{A}_{\text {slow }}$ were almost voltage independent with a value of $1.58 \pm 0.41(n=4)$ at $-50 \mathrm{mV}$. C, D Effects of washing out of $\mathrm{Mg}_{0}^{2+}$ on the voltage sensitivity of the decay time course of NMDA-EPSCs. The data shown were obtained from one cell perfused first with normal saline (squares) and then with nominally $\mathrm{Mg}^{2+}$-free saline (diamonds). Each EPSC trace was fitted with a biexponential function. The plotted points represent the mean and standard deviation $(n=6)$ of $\tau_{\text {fast }}(C)$ and $\tau_{\text {stow }}(D)$ at each membrane potential. E Schematic distinction between two processes contributing to enhancement of NMDA-EPSCs by moderate depolarization. The solid lines represent the time course of idealized NMDA-EPSCs evoked at $-70 \mathrm{mV}$ (a) and $-50 \mathrm{mV}$ (b), assuming that their decay follows the biexponential function given in the legend of Fig. $1 . \mathrm{A}_{\text {fast }}, \mathrm{A}_{\text {siow }}, \tau_{\text {fast }}$ and $\tau_{\text {siow }}$ are mean values based on the data from four cells shown in $\mathbf{A}$ and $\mathbf{B}$. The amounts of electric charge transferred by the EPSCs at -70 and at $-50 \mathrm{mV}$ were calculated by integrating the EPSCs over time, yielding 3.15 and $6.47 \mathrm{pC}$, respectively. Thus a $20 \mathrm{mV}$ depolarization from resting potential more than doubled the mean synaptic charge transfer (delineated by the shaded area). This increase is partially attributable to relief by depolarization of the fast $\mathrm{Mg}_{0}^{2+}$ block of NMDA-receptor channels. We estimated the contribution of this process to the total increase in synaptic charge transfer by assuming that it affects peak amplitudes of the EPSCs but does not alter their decay kinetics. The dotted line describes how EPSCs evoked at $-50 \mathrm{mV}$ would decay provided $\tau_{\text {fast }}$ and $\tau_{\text {slow }}$ were fixed at their $-70 \mathrm{mV}$ values. Under this assumption $\mathrm{Mg}_{0}^{2+}$ unblock by depolarization from -70 to $-50 \mathrm{mV}$ increases the synaptic charge transfer by $2.12 \mathrm{pC}$ (delineated by the shaded area above the dotted line). The remaining increase in synaptic charge transfer $(1.2 \mathrm{pC}$ delineated by the shaded area below the dotted line) is attributable to the voltage sensitivity of NMDA-EPSC decay membrane potential of the postsynaptic neurone. The molecular mechanism underlying this voltage sensitivity is probably different from the fast block of NMDAreceptor channels by $\mathrm{Mg}_{0}^{2+}$ (Nowak et al. 1984), which displays a much steeper voltage-dependence (e-fold change for $17 \mathrm{mV}$ depolarization, see Ascher and Nowak 1988) than we have observed for $\tau_{\text {fast }}$ and $\tau_{\text {slow }}$. However, $\mathrm{Mg}_{0}^{2+}$ may exert an additional blocking action of NMDA-receptor channels (Ascher et al. 1978) that occurs on a slower time-scale. Indeed, in all cells tested $(n=6)$, lowering the concentration of $\mathrm{Mg}_{0}^{2+}$ to a few micromoles/liter (see Methods), induced a prolongation of the decay time constants of NMDA-EPSCs (Figs. 1A, 2). This effect was strong at negative membrane potentials and was absent at positive potentials, indicating that $\mathrm{Mg}_{0}^{2+}$ modulates the EPSC time course postsynaptically rather than by influencing neurotransmitter release.

Even in nominally $\mathrm{Mg}^{2+}$-free solutions, however, both $\tau_{\text {fast }}$ and $\tau_{\text {slow }}$ retained a substantial voltage sensitivity (Fig. 2A-D). Furthermore, the voltage sensitivity of the EPSC time course at positive membrane potentials was unaffected by the washing out of $\mathrm{Mg}_{0}^{2+}$. These observations suggest that membrane voltage may also modulate the activity of NMDA receptor channels by a $\mathrm{Mg}_{0}^{2+}$-independent mechanism, although at present the action of residual $\mathrm{Mg}^{2+}$ in the micromolar concentration range cannot be ruled out.

Studies of non-NMDA-mediated EPSCs in central excitatory amino acid-operated synapses have shown either no effect (Nelson et al. 1986) or shortening (Brown and Johnston 1983) of EPSC decay by depolarization. We also found that the amplitude and time course of non-NMDA-EPSCs (isolated pharmacologically by bath application of \pm APV or CPP) in dentate granule cells are largely insensitive to voltage (unpublished observations). Thus the voltage sensitivity described here is a novel feature of NMDA-EPSCs that may play a role in neuronal plasticity. So far we can only speculate what this role may be. NMDA-receptor channels are permeable to $\mathrm{Ca}^{2+}$ (MacDermott et al. 1986). Extensive evidence (Collingridge and Bliss 1987) links $\mathrm{Ca}^{2+}$ entry through these channels to persistent alterations in neuronal function, e.g., long-term potentiation of excitatory synaptic transmission (Lynch et al. 1983; Malenka et al. 1988), kindling of epileptic seizures (Mody and Heinemann 1987) and ischemic cell death (Simon et al. 1984). Depolarization, as occurs during synaptic excitation, has been shown to promote $\mathrm{Ca}^{2+}$ entry by removing the fast $\mathrm{Mg}^{2+}$ block of NMDA-receptor channels. Our results indicate that depolarization will also enhance $\mathrm{Ca}^{2+}$ entry by prolonging the time course of NMDA-receptor-channel activation. The relative contribution of the latter mechanism would increase steeply with depolarization, but would be significant even near resting membrane potential. We estimate that upon depolarization of $20 \mathrm{mV}$ from resting potential in $1 \mathrm{mM} \mathrm{Mg}_{0}^{2+}$, about $36 \%$, of the increase in synaptic charge transfer through NMDA-receptor channels is due to the voltage sensitivity of the EPSC decay (Fig. 2E). If $\mathrm{Ca}^{2+}$ influx through these channels increases proportionately, then this mechanism may provide an important means of augmenting 
$\mathrm{Ca}^{2+}$ entry through NMDA-receptor-channels into depolarized neurones.

Acknowledgements. We thank Drs. G. Augustine, E. Neher and W. Stühmer for suggestions on early versions of the manuscript, and F. Friedlein for excellent technical assistance. This work was supported by the Deutsche Forschungsgemeinschaft (SFB 236), by a twinning grant from the European Science Foundation, and by a grant from the German-Israeli Foundation (GIF) for scientific research and development.

\section{References}

Andreasen M, Lambert JDC, Jensen MS (1989) Effects of new non-N-methyl-D-aspartate antagonists on synaptic transmission in the in vitro rat hippocampus. J Physiol 414:317-336

Ascher P, Marty A, Neild TO (1978) The mode of action of antagonists of the excitatory response to acetylcholine in Aplysia neurones. J Physiol 278: 207-235

Ascher P, Nowak L (1988) The role of divalent cations in the $\mathrm{N}$-methyl-D-aspartate responses of mouse central neurones in culture. J Physiol 399:247-266

Blake JF, Brown MW, Collingridge GL (1988) CNQX blocks acidic amino acid induced depolarizations and synaptic components mediated by non-NMDA receptors in rat hippocampal slices. Neurosci Lett 89:182-186

Brown TH, Johnston D (1983) Voltage-clamp analysis of mossy fiber synaptic input to hippocampal neurons. J Neurophysiol 50:487-507

Collingridge GL, Bliss TV (1987) NMDA-receptors: their role in long-term potentiation. TINS $10: 288-293$

Dale N, Roberts AJ (1985) Dual-component amino-acid mediated synaptic potentials: excitatory drive for swimming in Xenopus embryos. J Physiol 363:35-59

del Castillo J, Katz B (1954) Quantal components of the endplate potential. J Physiol 124:553-559

Edwards FA, Konnerth A, Sakmann B, Takahashi T (1989) A thin slice preparation for patch clamp recordings from neurones of the mammalian central nervous system. Pflügers Arch 414:600-612

Engberg I, Flatman JA, Lambert JDC (1979) The action of excitatory amino acids on motor neurons, in the feline spinal cord. J Physiol 288:227-261

Forsythe ID, Westbrook GL (1988) Slow excitatory postsynaptic currents mediated by $\mathrm{N}$-methyl-D-aspartate receptors on cultured mouse central neurones. J Physiol 396:515-533

Gustafsson B, Wigstrom H, Abraham WC, Huang Y-Y (1987) Long-term potentiation in the hippocampus using depolarizing current pulses as the conditioning stimulus to single volley synaptic potentials. J Neurosci 7:774-780

Hamill OP, Marty A, Neher E, Sakmann B, Sigworth FJ (1981) Improved patch-clamp techniques for high-resolution current recording from cells and cell-free membrane patches. Pflügers Arch 391:85-100

Hjorth-Simonsen A, Jeune B (1972) Origin and termination of the hippocampal perforant path in the rat studied by silver impregnation. J Comp Neurol (Lond) 144:215-232

Honoré T, Davies SN, Drejer J, Fletcher EJ, Jacobsen P, Lodge D, Nielsen FE (1988) Quinoxalinediones: potent competitive nonNMDA glutamate receptor antagonists. Science 241:701-703

Jahr CE, Stevens CF (1987) Glutamate activates multiple single channel conductances in hippocampal neurones. Nature $325: 522-525$

Larson J, Lynch G (1989) Theta pattern stimulation and the induction of LTP: the sequence in which synapses are stimulated determines the degree to which they potentiate. Brain Res 489:49-58

Lambert JDC, Jones RSG (1989) Activation of N-methyl-D-aspartate receptors contributes to the EPSP at perforant path synapses in the rat dentate gyrus in vitro. Neurosci Lett 97:323-328

Lynch G, Larson J, Kelso S, Barrionuevo G, Schottler F (1983) Intracellular injections of EGTA block induction of hippocampal long-term potentiation. Nature 305:719-721

MacDermott AB, Mayer ML, Westbrook GL, Smith SJ, Barker JL (1986) NMDA-receptor activation increases cytoplasmic calcium concentration in cultured spinal cord neurones. Nature $321: 519-522$

Malenka RC, Kauer JA, Zucker RS, Nicoll RA (1988) Postsynaptic calcium is sufficient for potentiation of hippocampal synaptic transmission. Science 242:81-84

Martell AE, Smith RM (1974) Critical stability constants, Vol. 2. Amines. Plenum Press, New York

Mayer ML, Westbrook GL (1987) Permeation and block of Nmethyl-D-aspartic acid receptor channels by divalent cations in mouse cultured central neurones. J Physiol 394:501-527

Mayer ML, Westbrook GL, Guthrie, PB (1984) Voltage-dependent block by $\mathrm{Mg}^{2+}$ of NMDA responses in spinal cord neurones. Nature 309:261-263

Mody I, Heinemann U (1987) NMDA receptors of dentate gyrus granule cells participate in synaptic transmission following kindling. Nature 326:701-704

Nelson PG, Pun RYK, Westbrook GL (1986) Synaptic excitation in cultures of mouse spinal cord neurones: receptor pharmacology and behaviour of synaptic currents. J Physiol 372:169-190

Nowak L, Bregestovski P, Ascher P, Herbet A, Prochiantz A (1984) Magnesium gates glutamate-activated channels in mouse central neurones. Nature 307:462-465

Pusch M, Conti F, Stühmer W (1989) Intracellular magnesium blocks sodium outward currents in a voltage- and dose-dependent manner. Biophys J 55:1267-1271

Simon RP, Swan JH, Griffith T, Meldrum BS (1984) Blockade of $\mathrm{N}$-methyl-D-aspartate receptors may protect against damage in the brain. Science 226:850-852

White WF, Nadler JV, Hamberger A, Cotman CW, Cummings JT (1977) Glutamate as transmitter of hippocampal perforant path. Nature 270:356-357 